\title{
The preservation state of the flora and vegetation of the artillery range near the city of Torun
}

\author{
Wanda Gugnacka-Fiedor, Edyta Adamska
}

\author{
Department of Taxonomy and Plant Geography, Institute of Ecology and Environment Protection, \\ Faculty of Biology and Earth Sciences, Nicolaus Copernicus University, \\ Gagarina 9, 87-100 Toruń, Poland, \\ e-mail: wgfiedor@biol.uni.torun.pl
}

\begin{abstract}
The floral and phytosociological research conducted between 1998-2001 in the area of the artillery range shows that there are 460 different species, including 363 vascular plants and 96 algae, bryophytes and lichens. The aforementioned count includes 45 taxa that are fully or partially protected. In the investigated area there are 30 species of vascular plants and 13 lichen species endangered to a different extent, referring to the scale of the whole region, for example: Aster amellus, Prunella grandiflora, Bryoria fuscescens, B. subcana, Peltigera praetextata and Ramalina fraxinea.

Out of 335 species recorded in the same area by German researchers in the late 19th century and the early 20th century, the occurrence of 270 species was confirmed by our research, which constitutes $80.6 \%$. The following species are considered as extinct, since they were not found again in the area: Adenophora liliifolia, Cephalanthera damasonium, C. rubra, Dracocephalum ruyschiana and Gladiolus paluster. During the one hundred years, which separate the two research projects, 95 new species appeared in the studied area, mostly archaeophytes and kenophytes.

According to the phytosociological research, there are 8 plant associations and one plant community in the unforested part of the range. Among the most rare associations, the following should be mentioned: Caricetum arenariae, Caricetum ligericae and FestucoKoelerietum glaucae. Calamagrostietum epigeji, Corniculario-Corynephoretum, Arctostaphylo-Callunetum are typical associations of this area. The association Scorzonero purpureae-Stipetum joannis and the community of Salix acutifolia-Epipactis atrorubens are the most valuable ones. They will become the most endangered associations if the excessive pressure by the army or the highway construction should cease in the future.

To preserve the particularly valuable species and plant associations, new active preservation forms should be introduced in the whole area of the artillery range, especially after cessation of the excessive military exploitation. A part of the artillery range called "Piaski" should be protected as a sanctuary because of the association Scorzonero purpureae-Stipetum joannis, which occurs only here.
\end{abstract}

Key words: flora, heathlands, inland dunes, plant associations, the artillery range, Torun and Bydgoszcz Valley.

\section{Introduction}

Among the numerous dune fields in Poland, the leading position is taken by areas of the Torun Valley, also known as the Valley of Torun and Bydgoszcz (Kondracki 2000; Andrzejewski 2001), which is a part of the Torun-Eberswald ice-marginal valley. Within the area of the valley, dunes are one of the dominant morphological elements over the area of $1850 \mathrm{~km}^{2}$.
The research deals with the vegetation of dune field IV, which has been exploited as the artillery range since the middle of the 17 th century. The oldest, published floristic data related to the studied area come from the papers by Scholz (1896), Abromeit et al. (1898) and Preuss (1912). At a later date, the research on the vegetation of dune areas within the Torun Valley was conducted on the Zadroże Dune, which is situated outside the artillery range (Anikiejówna \& Gorska 1949; Symonides 1972). Floristic peculiarities of this area were also described by: Walas (1969), 
Wilkoń-Michalska (1971), Ceynowa-Giełdon (1984), as well as Ceynowa-Giełdon and Nienartowicz (1994).

The main objectives of the present research was to make an inventory of the flora in the studied area, to describe plant communities, as well as to compare the present flora with its description from the turn of the 19th and 20th centuries. Moreover, an attempt was undertaken to evaluate how the land use method applied by the army, forestry and the local population affects the flora and the vegetation.

\section{General description of the study area}

The study area is located on dune field IV, defined also as the field of Torun, Aleksandrów and Gniewkowo (Mrózek 1958). Parabolic dunes are the dominant forms there. They developed on broad sandy terraces. They also developed on the bottom of the ice-marginal valley - on alluvial fans, outwash plains and fields built of fluvioglacial sand. During the Holocene, sandy areas together with dunes were covered with coniferous, mainly pine forests. Only logging of forests led to the intensification of aeolian processes, particularly during the last millennium (Klimaszewski 1978).

Nowadays, dunes in the Torun Valley are mostly inactive forms. They are usually covered with pine forest, less frequently with heaths and grassland communities. Parabolic dunes are the dominant morphological forms with arcs open towards the west. Apart from the arcuate forms, there are also linear dunes of latitudinal or almost longitudinal direction. The inclination of windward slopes, near the front of the dune, usually comes to $5-10^{\circ}$, and leeward slopes - to $12-20^{\circ}$ (Dorożyński 2001).

The artillery range has been exploited since the middle of the 17 th century until the present day, and it covers the area of $148.6 \mathrm{~km}^{2}$, confined within the following coordinates: E $018^{\circ} 29^{\prime}-018^{\circ} 44^{\prime}$ and N $052^{\circ} 51^{\prime}-052^{\circ} 59^{\prime}$ (Dorożyński 2001; Wasilewski 2003). In the area of the artillery range, there is a network of hardened paved roads, asphalt and concrete roads, numerous unhardened roads and routes, firebreaks, as well as engineering and technical buildings in the form of trenches and concrete bunkers - fire command posts. On the dune ridges, points of the geodetic control network are located, usually in the form of triangulation towers or landmarks. In the northern part, there are anti-tank barriers and foundations of barracks remains of the WWII POW camp; wells with horse water buckets are less frequent. Three tank traps run through the artillery range, with the original depth of ca. $4 \mathrm{~m}$. Military activities intensified mainly during the 1980s, when annual trainings on the artillery range gathered ca. 35,000 persons.

With the Regulation of the Provincial Governor of Toruń, dated December 10th, 1992, the artillery range was given the status of the protected landscape area - „Dune area to the south of Torun" - and it was included within the protective forest zone around the city; the area of which comes to 15657.2 ha (Burak 2001).

\section{Materials and methods}

Floristic and phytosociological studies in the area of the artillery range were carried out in 1998-2001. Lichens were collected mainly from the soil and the bark of roadside trees. The following guidebooks were used for the identification of the collected material: Szafran (1957-1961), Rejment-Grochowska (1971), Nowak and Tobolewski (1975), Purvis et al. (1992), Hindák (1996) and Rutkowski (2004). Names of taxa of vascular plants were provided according to Mirek et al. (2002). Nomenclature of liverworts was accepted after Klama (1996) and Szweykowski (2006), mosses after Ochyra et al. (2003), and lichens mostly after Diederich et al. (2009) and Santesson et al. (2004).

Specimens of lichens from the genus Cladonia, the group of chlorophaea, which were not subject to thin-layer chromatography TLC (Orange et al. 2001) were defined as Cladonia chlorophaea s.l.

In the phytosociological studies, the classic method of the French-Swiss school was applied (Pawłowski 1977). The relevés were made according to the 6-degree scale of Braun-Blanquet. The phytosociological studies covered non-forest areas of the artillery range. Altogether 82 relevés were made. At the same time, during few growing seasons, floristic notes were drawn up from different objects and habitats, including the information on population resources of selected species. The affinity of species to particular phytosociological classes was based on papers by Matuszkiewicz (2002), as well as Brzeg and Wojterska (2001). The list of protected species was prepared in compliance with the Regulation of the Minister of Environment dated 09.07.2004, whereas species endangered in the KujawyPomerania region and in Poland were determined based on the study of Cieśliński et al. (2006), Kaźmierczakowa and Zarzycki (2001), as well as Rutkowski (2005).

\section{Flora}

The number of species of native and domesticated vascular plants in the Kujawy-Pomerania region comes to ca. 1500 (Rutkowski 1997; Boinski et al. 2001). In the area of the artillery range, the presence of 460 species was confirmed, including 363 vascular plants, whereas the remaining 96 species are algae (1 species), bryophytes ( 25 species) and lichens (72 taxa). The following species are pioneers in the stabilization of dune sand: Klebsormidium crenulatum, Cetraria aculeata, Diploschistes muscorum, Polytrichum 
piliferum, Calamagrostis epigejos, Carex arenaria, Corynephorus canescens, Koeleria glauca and Leymus arenarius. In more stabilized, insolated and treeless areas, the following species occur in large numbers: Festuca trachyphylla, Hieracium pilosella, Spergula morisonii and Thymus serpyllum. A characteristic feature of the range landscape are heaths on hillsides of the dunes dominated by Arctostaphylos uva-ursi and Calluna vulgaris, usually accompanied by many species of cup lichens, including such taxa as: Cladonia cariosa, C. cenotea, C. crispata, C. gracilis ssp. elongata, C. gracilis ssp. turbinata, C. macilenta, C. rangiferina and $C$. squamosa. Among lichens seldom recorded in these communities, there are: Baeomyces rufus and Trapeliopsis granulosa. Crests of dunes are covered with the willow Salix acutifolia, which occurs in large numbers and is accompanied by: Hippophaë rhamnoides, Pinus sylvestris, Robinia pseudacacia and Salix repens, and in the herbaceous layer - Epipactis atrorubens is a very frequent component. On the exposed terraces, there occur species that are very seldom in other habitats of the artillery range: Alyssum montanum, Aster amellus, Avenula pratensis, Koeleria grandis, K. macrantha, Peucedanum cervaria, Prunella grandiflora, Pulsatilla patens, Scorzonera purpurea, Stipa joannis, Thesium ebracteatum, T. linophyllon, Trifolium lupinaster, Veronica austriaca, V. jacquinii and others. Most of them were recognized as nearly extinct, vulnerable and rare species in the region of the Kujawy-Pomerania Province (Rutkowski 2005). Cerasus fruticosa is a peculiarity of the artillery range. The species is threatened with extinction; it is present at few sites, including „Góra Żymierskiego”, where it is subject to burning off, repeated several times every year (a field of fire). In the vicinity of „Góra Dziwak”, on the shores of a small water reservoir, overgrown with vegetation, the presence of a very rare liverwort was recorded - Riccia huebeneriana. Mosses occurred only on bunkers and others concrete constructions - Grimmia apocarpa and G. pulvinata. Constructions of any kind were accompanied by species of alien origin, including for instance: Amaranthus retroflexus, Galinsoga parviflora, Lepidium densiflorum, Oenothera acutifolia, $O$. hoelscheri, O. pycnocarpa, O. royfraseri, O. depressa, and at a transfer station in the village of Otłoczyn, Sporobolus cryptandrus was found.

At present, the flora of the artillery range comprises 47 protected species (Table 1), including 30 taxa strictly protected by law and 17 taxa partially protected. Only 17 species were recognized as endangered countrywide (Cieśliński et al. 2006; Kaźmierczakowa \& Zarzycki 2001), including lichens: in the category of critically endangered species (CR) - Bryoria subcana, endangered species (EN) Ramalina fraxinea; $B$. fuscescens and Peltigera praetextata, as well as plants: Prunus fruticosa and Pulsatilla patens were recognized as vulnerable species. As many as 30 species, endangered on a regional scale, occur in the area of the artillery range, including species threatened with extinction - Aster amellus and Prunella grandiflora.

Out of the 335 species of vascular plants listed from the artillery range by Scholz (1896), Abromeit et al. (1898) and Preuss (1912), the presence of 270 species was confirmed during the current research, which constitutes $80.6 \%$ of the original state. The group of 65 species (19.4\%), not recorded for the second time, includes species recognized as extinct in the region: Adenophora liliifolia, Cephalanthera damasonium, C. rubra, Dracocephalum ruyschiana and Gladiolus paluster.

During the century separating the two research periods, the artillery range gained 95 new species, usually kenophytes: Acer negundo, Amelanchier spicata, Armoracia rusticana, Cotinus coccygria, Echinocystis lobata, Padus serotina, P. virginiana, Pinus strobus, Robinia pseudoacacia, Sisymbrium loeselii, Solidago gigantea, S. canadensis, the aforementioned species from the genus Oenothera and archaeophytes: Descurainia sophia, Digitaria ischaemum, Lepidium ruderale, Papaver rhoeas and others.

\section{Plant communities}

The phytosociological studies on the non-forest area of the artillery range proved the presence of 8 associations and one plant community (Table 2 ). They are classified within 5 classes:

Cl. Epilobietea angustifolii R. Tx. et Prsg. 1950 in R. Tx. in R. Tx. 1950

O. Epilobietalia angustifolii R. Tx. 1950

All. Epilobion angustifolii R. Tx. 1950

1. Calamagrostietum epigeji Juraszek 1928

Cl. Koelerio-Corynephoretea Klika in Klika et Novak 1941

O. Corynephoretalia canescentis Klika 1934

All. Corynephorion canescentis Klika 1931

2. Corniculario-Corynephoretum (R. Tx. 1928) Steffen 1931

3. Caricetum arenariae Steffen 1931

O. Festuco-Sedetalia R. Tx. 1951 em. Krausch 1962

All. Koelerion glaucae (Volk 1931) Klika 1934

4. Caricetum ligericae Kępczyński et Rutkowski 1988

5. Festuco-Koelerietum glaucae Klika 1931

6. Festuco psammophilae-Elymetum arenarii (Kobendza 1930) Celiński et

Balcerkiewicz 1973 ex Brzeg et M. Wojterska (1996) 2001

Cl. Festuco-Brometea Br.-B1. ex R. Tx. 1943

O. Festucetalia valesiacae Br.-Bl. et R. Tx. 1943

7. Scorzonero purpureae-Stipetum joannis (Ceynowa 1968) Brzeg in Brzeg et M. Wojterska 2001 
Cl. Calluno-Ulicetea Br.-Bl. ex R. Tx. 1943 em. Prsg 1949

O. Vaccinio-Genistetalia Scgubert 1960

All. Calluno-Arctostaphylion R. Tx. et Prsg 1949 ex Faliński 1965

8. Arctostaphylo-Callunetum (Juraszek 1928) R. Tx. et Prsg. 1940 ex Faliński 1965

Cl. Erico-Pinetea Horvat 1959 (?)

O. Erico-Pinetalia Horvat 1959

All. Erico-Pinion Br.-Bl. in Br.-B1. et al. 1939

9. The community Salix acutifolia-Epipactis atrorubens

The association Calamagrostietum epigeji is the most common one in the studied area. It occurs mainly in the central and southern part of the artillery range. Despite the field occurrence, the population of Calamagrostis epigejos does not reduce the development of other plants, therefore it consists of 65 species of vascular plants, 12 taxa of lichens and 10 mosses. Apart from the dominant species, also species from the classes Nardo-Callunetea and Festuco-Brometea occur in relatively large numbers. The association is composed of rare species, such as: Oenothera pycnocarpa, O. royfraseri, Pulsatilla pratensis and Rosa sherardii. The aforementioned association is extremely expansive. In the southern part of the artillery range, it became a dominant community and it continuously extends its range of occurrence.

Also Corniculario-Corynephoretum is one of the most common associations within the artillery range. It is composed of 59 species, including 39 species of vascular plants, 4 species of mosses, 15 taxa of lichens and 1 alga. Corynephorus canescens and Spergula morisonii are the dominant species. In the initial phases of the association, the vegetation structure is very scattered, and at first the turfs of Polytrichum piliferum and thalli of Klebsormidium crenulatum appear on the sand. In the layer of lichens and mosses, Cetraria aculeata, Cladonia macilenta and C. cervicornis dominate. Among the accompanying plants, species from the class Nardo-Callunetea occur in large numbers, particularly Carex ericetorum.

Caricetum arenariae is yet another association described by Kępczyński and Rutkowski (1988) from the Torun Valley. It is species rich and comprises 34 vascular species, 13 lichens and 6 bryophytes. It covers small areas $\left(50-300 \mathrm{~m}^{2}\right)$ in the northern and western part of the artillery range. Only occasionally it plays a role of an initial community, contributing to the stabilization of dunes. The remaining species from the class Koelerio-Corynephoretea, and particularly Helichrysum arenarium and Polytrichum piliferum play an important role in the association.

The association Caricetum ligericae also occurs on small areas in the northern part of the range, often in the vicinity of the association of the sand sedge. It prefers stabilized sand with a well developed soil (Kępczyński
\& Rutkowski 1988). The composition of the association comprises 50 species, including as many as 47 vascular plants, and just 1 moss and 2 lichen species. Carex ligerica dominates in all the studied patches.

The association Festuco-Koelerietum glaucae is one of the rarest associations within the artillery range and some larger patches are present only at two sites in its central part. Floristically it is quite poor -34 species, including 28 species of vascular plants, 3 lichens and 3 mosses. Koeleria glauca is the dominant species, whereas Hieracium pilosella and Festuca duvalii are codominants. Locally Tragopogon floccosus is a good differential species. The association is floristically poorer than the one described by Symonides (1972) from the Zadroże Dune, where the presence of 49 species of vascular plants was recorded, as well as 10 species of lichens and 1 moss species. In the Wielkopolska Region, Brzeg and Wojterska (2001) defined this community as rare, exposed to impoverishment and simplification of the structure.

The association Elymetum arenarii is a pioneer community growing on dunes. Its occurrence in the Vistula River valley is accounted for by migration from coastal areas and by human activity. Within the artillery range, it covers elevated roadsides, firebreaks strips and tank routes. Patches of the association are usually small and occur mainly in the northern part of the range. The association is characterized by a small contribution of characteristic species, mainly Corynephorus canescens and Polytrichum piliferum. This is the community where Klebsormidium crenulatum occurs again. 45 species were recorded in the association, including 32 vascular plants, 9 lichens and 4 mosses. Similarly like in the Wielkopolska Region, it is a rare xenospontaneous community under indeterminate threat (Brzeg \& Wojterska 2001).

The class Festuco-Brometea is represented by the association Scorzonero purpureae-Stipetum joannis, and present mainly in the eastern part of the range („Piaski”). Within the remaining area, it occurs in the form of small patches on the slopes of dunes, in the depressions between elevations and along roadsides. The association is species rich. It comprises 90 species, including 68 species of vascular plants, 14 species of lichens and 8 species of bryophytes. Between tussocks of Stipa joannis, the following species grow: Asperula tinctoria, Filipendula vulgaris, Helianthemum nummularium ssp. obscurum, Phleum phleoides, Pulsatilla pratensis, Scorzonera purpurea, Thesium linophyllon, Veronica jacquinii and others. In the Wielkopolska Region, this association has the status of a very rare community, directly threatened with extinction (Brzeg \& Wojterska 2001).

The class Calluno-Ulicetea is represented by the association Arctostaphylo-Callunetum, which occurs mainly in the central part of the range, mainly on the slopes of dunes, less frequently on flat areas. It is the richest association in 
floristic respect. 94 species were recorded in its patches, including 57 species of vascular plants, 27 lichens and 10 mosses. The following species had the highest cover degrees in the association: Calluna vulgaris, Arctostaphylos uva-ursi and Polytrichum piliferum. In the layer of lichens and mosses, taxa from the genus Cladonia dominate, such as: Cladonia arbuscula ssp. arbuscula, C. arbuscula ssp. mitis, C. cervicornis, C. floerkeana, C. pleurota, C. portentosa, $C$. rangiferina and others. This association (under indeterminate threat) is widespread in the Torun Valley.

Epipactis atrorubens, the population of which comes to ca. 2300 specimens within the artillery range, occurs as a component of thickets and xerothermic grasslands in central Europe, for instance from the class of Erico-Pinetea. The presence of this species on coastal dunes, stabilized also by planting of Salix acutifolia, was described by e.g. Wojterski (1957), Wojterski and Bednorz (1982) and Filinger (1992). It seems that this helleborine species prefers poorly stabilized dunes, bare or overgrown with thermophilous thickets of shrubs, including willows.

The presented community of Salix acutifolia-Epipactis atrorubens is rich in species. It is composed of 66 species of vascular plants, 11 species of bryophytes and 19 taxa of lichens. Only in this community Botrychium lunaria grows at one location. Astragalus arenarius, Festuca psammophila and Helichrysum arenarium occur in the largest numbers. The average cover of the shrub layer comes to 29\%. Apart from Salix acutifolia, also the following species occur here: Berberis vulgaris, Betula pendula, Crataegus monogyna, Frangula alnus, Pinus sylvestris, Populus x canescens, P. tremula, Padus serotina, P. virginiana, Pyrus pyraster, Quercus robur and Sorbus aucuparia. The community can be threatened by ceasing the military penetration of dune crests, as well as by the increased density of the shrub layer or the domination of these habitats by Calamagrostis epigejos.

\section{Summary and conclusions}

The artillery range near Torun, as a protected landscape area, is covered with multiage forests and heaths in $99.4 \%$. Despite the fact that other communities and bare dunes cover only ca. $0.6 \%$ of the total area, it is very rich in species. The flora of this area consists of 25 species of bryophytes, 363 vascular species and 72 taxa of lichens. 47 protected species occur here and 28 species vulnerable to extinction to a different extent. Since the previous research, from the turn of the 19th and 20th centuries, 65 species were lost. Among them, there are species recognized as extinct in the region: Adenophora liliifolia, Cephalanthera damasonium, C. rubra, Dracocephalum ruyschiana and Gladiolus paluster. In the previous century, this area was enriched with 99 new species, mostly kenophytes (189 species of synanthropic plants were recorded in the studied area).

Different activities of the armed forces, including cutting of trees and shrubs, different types of training and frequent fires, brought about also by the local civilian population, contribute to the preservation of habitats covered with non-forest communities, including the association Scorzonero purpureae-Stipetum joannis - very rare and threatened with extinction.

In order to preserve the particularly valuable species and plant communities, it is necessary to introduce some forms of active protection for the whole artillery range, especially after ceasing the exploitation of this area by the army. Part of the artillery range, where the large population of Stipa joannis occurs („Piaski”), should be designated as a nature reserve, where it would be necessary to remove young specimens of Scots pine. Cerasus fruticosa is yet another species, the population size of which should be monitored regularly. It is a species threatened with extinction, at least within a certain part of the artillery range.

Further research, together with searching for locations of species recognized as currently extinct, as well as the documentation of all nature and aesthetic values of the artillery range is worthwhile of a separate research programme. It is also indispensable to introduce the natural values to residents of Torun and the nearby towns and villages, for whom the artillery range is a valued area for walks and mushroom picking.

\section{Acknowledgments}

The authors wish to express their gratitude to the Command and the Cadre of the Garrison in Torun, in particular the colonel J. Majkut for permits to conduct the research and the colonel H. Buryta for his cooperation regarding the history of the artillery range, as well as for sharing his knowledge on the topography of the area and places of great natural value. The authors are grateful to Mr K. Stańczak from the Regional Directorate of State Forests in Torun for providing the comprehensive information on the status of the artillery range as a part of protective forests. 
Table 1. The preserved plants in the area of the artillery range near Torun

\begin{tabular}{|c|c|c|c|c|}
\hline \multirow{2}{*}{ Takson } & \multicolumn{2}{|c|}{ Full protection } & \multicolumn{2}{|c|}{ Part protection } \\
\hline & $\mathrm{XIX} / \mathrm{XX}$ w. & XX/XXI w. & XIX/XX w. & XX/XXI w. \\
\hline \multicolumn{5}{|c|}{ Lichenes: } \\
\hline Bryoria fuscescens (Gyeln.) Brodo \& D. Hawksw. & - & ++ & . & . \\
\hline Bryoria subcana (Stizenb.) Brodo \& D. Hawksw. & - & + & . & . \\
\hline Cetraria aculeata (Schreb.) Fr. & . & . & . & +++ \\
\hline Cetraria islandica (L.) Ach. ssp. islandica & . & . & . & ++ \\
\hline Cladonia arbuscula (Wallr.) Flot. subsp. arbuscula & - & . & . & ++ \\
\hline Cladonia arbuscula (Wallr.) Flot. subsp. mitis (Sandst.) Ruoss & . & . & . & +++ \\
\hline Cladonia ciliata Stirt. & - & . & . & + \\
\hline Cladonia portentosa (Dufour) Coem. & . & . & . & ++ \\
\hline C. rangiferina (L.) F. H. Wigg. & . & . & . & + \\
\hline Evernia prunastri (L.) Ach. & - & . & . & ++ \\
\hline Hypogymnia tubulosa (Schaer.) Hav. & - & + & . & . \\
\hline Peltigera canina (L.) Willd. & . & ++ & . & . \\
\hline Peltigera didactyla (With.) J. R. Laundon & - & ++ & . & . \\
\hline Peltigera polydactylon (Neck.) Hoffm. & - & + & . & . \\
\hline Peltigera praetextata (Sommerf.) Zopf & - & + & . & . \\
\hline Peltigera rufescens (Weiss) Humb. & . & +++ & . & . \\
\hline Platismatia glauca (L.) W.L. Culb \& C.F. Culb. & - & +++ & . & . \\
\hline Pseudevernia furfuracea (L.) Zopf & - & ++ & . & . \\
\hline Ramalina fraxinea (L.) Ach. & - & + & . & . \\
\hline Usnea hirta (L.) F. H. Wigg. & . & + & . & . \\
\hline Tuckermannopsis sepincola (Ehrh.) Hale & - & + & . & . \\
\hline \multicolumn{5}{|c|}{ Marchantiophyta: } \\
\hline Ptilidium ciliare (L.) Hampe & - & . & . & + \\
\hline Riccia huebeneriana Lindenb. & - & + & . & . \\
\hline \multicolumn{5}{|c|}{ Bryophyta: } \\
\hline Dicranum scoparium Hedw. & . & . & . & ++ \\
\hline Pleurozium schreberi Mitt. & . & . & . & ++ \\
\hline Polytrichum commune L. & . & . & . & + \\
\hline \multicolumn{5}{|c|}{ Pteridophyta: } \\
\hline Botrychium lunaria (L.) Sw. & + & + & . & . \\
\hline Botrychium multifidum (S. C. Gmel.) Rupr. & + &.. & . & . \\
\hline Diphasiastrum tristachyum (Pursh) Holub & + & . & . & . \\
\hline Diphasiastrum complanatum (L.) Holub & + & . & . & . \\
\hline
\end{tabular}




\begin{tabular}{|c|c|c|c|c|}
\hline Polypodium vulgare L. & + & + & . & . \\
\hline \multicolumn{5}{|l|}{ Spermatophyta: } \\
\hline Adenophora liliifolia (L.) Besser & + & . & . & . \\
\hline Arctostaphylos uva-ursi (L.) Spreng. & +++ & +++ & . & . \\
\hline Aster amellus L. & + & + & . & . \\
\hline Carex arenaria $\mathrm{L}$. & . & . & . & ++ \\
\hline Carlina acaulis $\mathrm{L}$. & + & . & . & . \\
\hline Centaurium erythraea Rafn & . & + & . & . \\
\hline Cephalanthera damasonium (Miller) Druce & + & . & . & . \\
\hline Cephalanthera rubra (L.) L. Rich. & + & . & . & . \\
\hline Cerasus fruticosa Pall. & +++ & + & . & . \\
\hline Cimicifuga europaea Schipcz. & + & . & . & . \\
\hline Convallaria majalis $\mathrm{L}$. & - & . & ++ & +++ \\
\hline Dianthus arenarius L. & + & ++ & . & . \\
\hline Dianthus superbus L. & + & . & . & . \\
\hline Dracocephalum ruyschiana $\mathrm{L}$. & + & . & . & . \\
\hline Epipactis atrorubens (Hoffm.) Besser & ++ & +++ & . & . \\
\hline Epipactis helleborine (L.) Crantz & + & . & . & . \\
\hline Frangula alnus Mill. & - & . & ++ & ++ \\
\hline Gladiolus paluster Gaudin & + & . & . & . \\
\hline Gymnadenia conopsea (L.) R. Br. & + & . & . & . \\
\hline Helichrysum arenarium (L.) Moench & . & . & ++ & +++ \\
\hline Hierochloë australis (Schrad.) Roem. \& Schult. & . & . & + & . \\
\hline Hippophaë rhamnoides L. & . & + & . & . \\
\hline Lilium martagon $\mathrm{L}$. & + & . & . & . \\
\hline Oxytropis pilosa (L.) DC. & ++ & + & . & . \\
\hline Primula veris $\mathrm{L}$. & . & . & + & . \\
\hline Pulsatilla patens (L.) Mill. ssp. patens & ++ & + & . & . \\
\hline Pulsatilla pratensis (L.) Mill. & +++ & ++ & . & . \\
\hline Ribes nigrum L. & - & . & + & + \\
\hline Scorzonera purpurea L. & ++ & + & . & . \\
\hline Sorbus intermedia (Ehrh.) Pers. & . & + & . & . \\
\hline Stipa joannis Čelak & + & ++ & . & . \\
\hline Thesium ebracteatum Hayne & ++ & + & . & . \\
\hline Vinca minor $\mathrm{L}$. & - & . & + & - \\
\hline
\end{tabular}

Explanations:

XIX/XX century - data by Scholz (1896), Abromeit et al. (1898) and Preuss (1912), XX/XXI century - own collected data 1998-2002; the frequency of occurring: +++ - often, ++ - quite often, +- rarely, -- no data, . - species not occurring during the research period 
Table 2. Selected communities on the artillery range near Torun: 1 - Calamagrostietum epigeji, 2 - Corniculario-Corynephoretum, 3 -Caricetum arenariae, 4 - Caricetum ligericae, 5 - Festuco-Koelerietum glaucae, 6 - Elymetum arenarii, 7 - Scorzonero purpureae-Stipetum joannis, 8 - Arctostaphylo-Callunetum, 9 - community Salix acutifolia-Epipactis atrorubens

\begin{tabular}{|c|c|c|c|c|c|c|c|c|c|}
\hline Community Species & 1 & 2 & 3 & 4 & 5 & 6 & 7 & 8 & 9 \\
\hline Number of records & 9 & 10 & 5 & 4 & 3 & 10 & 10 & 20 & 8 \\
\hline Mean number of species in the record & 18 & 15 & 19 & 22 & 22 & 11 & 26 & 25 & 33 \\
\hline Number of species in community & 87 & 59 & 53 & 50 & 34 & 45 & 90 & 94 & 96 \\
\hline $\begin{array}{l}\text { Mean of plant cover }(\%) \\
\text { a } \\
b \\
\text { c } \\
d\end{array}$ & $\begin{array}{c}- \\
1 \\
82 \\
12\end{array}$ & $\begin{array}{l}- \\
0,5 \\
54 \\
51\end{array}$ & $\begin{array}{l}- \\
- \\
92 \\
32\end{array}$ & $\begin{array}{l}- \\
- \\
85 \\
24\end{array}$ & $\begin{array}{l}- \\
- \\
57 \\
47\end{array}$ & $\begin{array}{c}- \\
- \\
84 \\
7\end{array}$ & $\begin{array}{c}- \\
4 \\
80 \\
31\end{array}$ & $\begin{array}{l}- \\
2 \\
83 \\
42\end{array}$ & $\begin{array}{c}33 \\
3 \\
66 \\
47\end{array}$ \\
\hline \multicolumn{10}{|l|}{ Epilobietea angustifolii: } \\
\hline Calamagrostis epigejos & V 6528 & IV 104 & II 4 & & 13 & II 51 & IV 377 & III 30 & II 471 \\
\hline \multicolumn{10}{|l|}{ Koelerio-Corynephoretea: } \\
\hline Corynephorus canescens & III 113 & V 4550 & IV 104 & 2250 & 13 & V 206 & III 477 & V 34 & II 65 \\
\hline Hieracium pilosella & II 3 & IV 5 & III 6 & 38 & 3173 & III 4 & III 54 & IV 11 & V 9 \\
\hline Helichrysum arenarium & I 1 & I 1 & II 102 & 4133 & 310 & II 3 & IV 6 & I 1 & V 9 \\
\hline Polytrichum piliferum & III 306 & V 233 & V 190 & & 13 & IV 429 & $\begin{array}{c}\text { IV } \\
1001\end{array}$ & V 1783 & II 221 \\
\hline Ceratodon purpureus & IV 170 & I 2 & II 4 & & 27 & II 3 & II 600 & I 1 & I 1 \\
\hline Brachythecium albicans & I 1 & I 2 & I 2 & & 27 & I 1 & III 5 & I 1 & II 1 \\
\hline Potentilla argentea & I 1 & I 1 & I 100 & 38 & 13 & & IV 7 & I 1 & \\
\hline Jasione montana & II 2 & I 2 & III 6 & 13 & & II 3 & II 3 & II 3 & \\
\hline Koeleria glauca & & & II 4 & 13 & 33917 & II 51 & II 52 & III 78 & IV 470 \\
\hline Carex arenaria & I 1 & I 1 & V 3625 & 13 & & I 1 & & I 1 & \\
\hline Festuca trachyphylla & II 2 & III 178 & II 102 & 38 & & & III 752 & IV 153 & III 2096 \\
\hline Cetraria aculeata & & III 177 & II 102 & & 13 & III 14 & III 4 & IV 31 & III 128 \\
\hline Tragopogon floccosus & I 1 & I 2 & & 25 & 27 & III 14 & & I 2 & II 4 \\
\hline Spergula morisonii & & IV 55 & I 2 & 13 & & III 4 & I 1 & II 3 & \\
\hline Hypericum perforatum & III 58 & & II 4 & 2128 & & & III 5 & II 2 & \\
\hline Cladonia foliacea & I 1 & I 2 & II 102 & & & & IV 104 & I 1 & II 126 \\
\hline Rumex acetosella & II 2 & I 2 & & & & II 2 & III 4 & III 30 & II 1 \\
\hline Thymus serpyllum & III 59 & II 51 & & 13 & & & II 2 & II 28 & II 1 \\
\hline Galium verum & III 198 & & & 25 & & & IV 203 & II 2 & II 1 \\
\hline Agrostis vinealis & I 1 & I 2 & & & & II 2 & II 2 & II 53 & \\
\hline Scleranthus perennis & & II 3 & & & 13 & I 1 & I 1 & I 1 & \\
\hline Festuca ovina & I 1 & I 2 & & & & & & I 51 & II 500 \\
\hline Trifolium arvense & & & & 2128 & 27 & & II 2 & & I 1 \\
\hline Silene otites & I 1 & & I 2 & & 13 & & & & II 4 \\
\hline Festuca psammophila & & I 1 & & & & II 2 & & & IV 877 \\
\hline Astragalus arenarius & & I 1 & & & & & & I 2 & III 128 \\
\hline Knautia arvensis & I 1 & & & 25 & & & I 1 & & \\
\hline Leymus arenarius & & & & 13 & & V 7000 & & & \\
\hline Carex ligerica & & & & 45625 & & I 1 & & & \\
\hline
\end{tabular}




\begin{tabular}{|c|c|c|c|c|c|c|c|c|c|}
\hline \multicolumn{10}{|l|}{ Festuco-Brometea: } \\
\hline Euphorbia cyparissias & II 2 & & I 2 & 13 & 27 & II 52 & IV 55 & II 2 & III 5 \\
\hline Artemisia campestris & I 1 & I 1 & I 2 & 410 & 310 & & I 1 & & I 1 \\
\hline Asparagus officinalis & I 1 & I 1 & & 13 & & & & & II 65 \\
\hline Dianthus carthusianorum & II 3 & & & II 5 & & & V 57 & II 3 & I 1 \\
\hline Centaurea stoebe & & I 1 & & 25 & 27 & & II 52 & & \\
\hline Potentilla arenaria & II 13 & & & 25 & & & III 5 & I 1 & II 1 \\
\hline Veronica spicata & II 2 & & & 25 & & & III 4 & I 1 & I 1 \\
\hline Centaurea scabiosa & I 1 & & & & & & I 1 & & III 5 \\
\hline Stipa joannis & & & & & & & V 3375 & & \\
\hline \multicolumn{10}{|l|}{ Trifolio-Geranietea: } \\
\hline Agrostis capillaris & II 13 & II 52 & II 4 & 2128 & & III180 & II 377 & II 29 & \\
\hline Poa angustifolia & I 1 & & & 13 & & II 2 & II 3 & & II 1 \\
\hline \multicolumn{10}{|l|}{ Calluno-Ulicetea: } \\
\hline Peucedanum oreoselinum & II 5 & IV 6 & II 102 & & & I 1 & V 8 & IV 32 & I 1 \\
\hline Calluna vulgaris & III 59 & III 4 & II 102 & & & I 1 & II 3 & V 6776 & \\
\hline Carex ericetorum & III 59 & IV 153 & & & & I 1 & IV 6 & IV 31 & I 1 \\
\hline Hieracium umbellatum & & & II 4 & 13 & & I 1 & & III 78 & III 128 \\
\hline Viola canina & II 3 & & & & 13 & & & I 26 & I 1 \\
\hline Arctostaphylos uva-ursi & & I 1 & & & & & & $\begin{array}{c}\text { IV } \\
3112 \\
\end{array}$ & \\
\hline \multicolumn{10}{|l|}{ Remaining: } \\
\hline Cladonia arbuscula & II 2 & I 1 & III 104 & 4255 & & I 1 & II 3 & III 362 & II 470 \\
\hline Cladonia macilenta & II 2 & I 52 & III 4 & 2128 & & I 1 & III 4 & V 204 & I 1 \\
\hline Cladonia pyxidata & I 1 & I 2 & II 102 & 13 & & I 1 & II 52 & II 28 & I 1 \\
\hline Pinus sylvestris $\mathrm{a}, \mathrm{b}, \mathrm{c}$ & & I 2 & I 2 & 13 & 13 & & I 1 & II 28 & V 690 \\
\hline Chondrilla juncea & I 1 & & I 2 & 13 & 27 & III 4 & I 1 & I 1 & \\
\hline Conyza canadensis & I 1 & III 4 & & 13 & 27 & I 1 & I 1 & & \\
\hline Cladonia phyllophora & I 1 & I 2 & I 2 & & & I 2 & II 3 & III 4 & I 1 \\
\hline Cladonia cornuta & II 3 & IV 55 & III 6 & & & III 4 & III 54 & II 27 & I 1 \\
\hline Solidago virgaurea & I 1 & III 102 & I 2 & & & I 1 & II 2 & & IV 6 \\
\hline Cladonia fimbriata & I 1 & I 1 & & & & I 1 & II 2 & I 1 & I 1 \\
\hline Cladonia uncialis & & & I 2 & & & I 1 & III 401 & II 4 & I 1 \\
\hline Carex hirta & I 1 & & I 2 & 38 & & II 52 & & I 1 & \\
\hline Achillea millefolium & & & & 25 & 310 & II 1 & III 4 & I 1 & \\
\hline Cladonia chlorophaea s.l. & I 1 & I 1 & I 2 & & & & III 54 & & I 1 \\
\hline Linaria vulgaris & II 2 & & I 2 & 2128 & & & II 2 & & II 1 \\
\hline Cladonia rangiformis & I 1 & & & & & I 1 & II 3 & II 27 & I 1 \\
\hline Populus tremula b, c & III 3 & I 1 & & & & & II 2 & I 1 & I 1 \\
\hline Pleurozium schreberi & I 1 & & & 3375 & & & IV 652 & I 1 & \\
\hline Cladonia cervicornis & & II 3 & II 4 & & 13 & & & III 78 & \\
\hline Hypnum cupressiforme & II 2 & & & & & & I 1 & I 1 & II 65 \\
\hline Cladonia subulata & II 2 & & I 2 & 25 & & & & I 2 & \\
\hline
\end{tabular}




\begin{tabular}{|c|c|c|c|c|c|c|c|c|c|}
\hline Convolvulus arvensis & & & & 13 & 13 & I 1 & I 1 & & \\
\hline Cephaloziella starkei & & I 1 & & & & II 3 & I 1 & II 2 & \\
\hline Betula pendula & II 2 & I 1 & & & & & I 1 & II 2 & \\
\hline Deschampsia flexuosa & I 1 & I 1 & I 2 & & & & & II 52 & \\
\hline Anthericum ramosum & II 2 & & I 2 & & & & & III 55 & II 1 \\
\hline Convallaria majalis & II 2 & I 2 & & & & & & II 27 & II 4 \\
\hline Padus serotina $\mathrm{b}, \mathrm{c}$ & & I 2 & I 2 & & & & & I 1 & III 5 \\
\hline Dicranum scoparium & II 2 & & & & & & I 1 & I 1 & I 1 \\
\hline Cladonia portentosa & & I 1 & & & & & I 1 & I 1 & II 1 \\
\hline Vincetoxicum hirundinaria & II 3 & I 1 & & & & I 1 & I 1 & & II 1 \\
\hline Lotus corniculatus & I 1 & I 1 & & & & & & I 1 & I 1 \\
\hline Festuca duvalii & & & & & 3173 & II 51 & I 1 & & \\
\hline Vicia tetrasperma & & & & 13 & & & II 52 & & IV 68 \\
\hline Polygonatum odoratum & III 4 & I 1 & & & & & & III 5 & IV 68 \\
\hline Cetraria islandica & & I 2 & & & & & & II 4 & IV 68 \\
\hline Sedum acre & & & & & 310 & & I 1 & & II 65 \\
\hline Oenothera rubricaulis & II 2 & & & & & II 51 & I 1 & & \\
\hline Cladonia furcata & I 1 & & & & & & & I 26 & III 5 \\
\hline Oenothera biennis & & & II 4 & & 27 & & & & II 1 \\
\hline Trifolium alpestre & & & & 13 & & & II 2 & & I 1 \\
\hline Trifolium campestre & & & & 13 & & & & I 1 & I 1 \\
\hline Pulsatilla pratensis & I 1 & & & 13 & & & I 1 & & \\
\hline Cladonia coniocraea & & I 1 & I 2 & & & & & I 1 & \\
\hline Sorbus aucuparia b & I 1 & & & & & & & I 1 & I 1 \\
\hline
\end{tabular}

Gatunki sporadyczne - occasional species:

Epilobietea angustifolii: Centaurium erythraea (9/II 1), Chamaenerion angustifolium (1/I 1)

Koelerio-Corynephoretea: Arenaria serpyllifolia (7/II 2; 9/II 1), Armeria maritima (7/I 1), Dianthus arenarius (2/I 1; 8/I 1), Plantago arenaria (2/I 1), Rhacomitrium canescens (3/I 2; 7/I 1), Silene chlorantha (5/1 3), Teesdalea nudicaulis (3/II 102)

Festuco-Brometea: Asperula tinctoria (7// 1), Carex praecox (7// 1), Filipendula vulgaris (7// 1), Helianthemum nummularium ssp. obscurum (7/II 3), Koeleria pyramidata (7/I 1), Phleum phleoides (7/II 51), Poa compressa (1// 1), Salvia pratensis (7/II 3), S. verticillata (1/I 1), Scabiosa canescens (7/II 2), S. ochroleuca (8/I 1), Scorzonera purpurea (7// 1), Thesium linophyllon (7/I 1), Veronica austriaca $(7 / / 1)$

Remaining: Anchusa officinalis (1/I 1), Anthoxanthum odoratum (3/I 2), Arabidopsis thaliana (4/1 3), Berberis vulgaris b (1/I 1; 9/IV 8), Berteroa incana (5/2 7; 7/I 1), Botrychium lunaria (9/I 1), Brachythecium salebrosum (9/I 1), B. velutinum (9/I 1), Bryum inclinatum (1/I 1), Campanula rotundifolia (1/I 1;8/V 1), Cardaminopsis arenosa (9/I 1), Carex pilulifera (8/I 1), Carlina vulgaris (9/I 1), Cerastium holosteoides (7// 1), Chiloscyphus polyanthos (9/II 1), Cladonia cenotea (8/I 1), C. ciliata (9/II 471), C. coccifera (3/I 2; 8/II 90), C. crispata $(2 / / 1 ; 8 / I 1)$, C. deformis (8/II 3), C. glauca (9/I 1), C. gracilis (8/II 51), C. pleurota (7/I 1; 8/III 4), C. rangiferina (1/I 1; 8/I 1), C. squamosa (9/I 1), C. symphycarpa (9// 1), Coronilla varia (7/II 2), Crataegus monogyna (9// 1), Sarothamnus scoparius (8/I 1), Diploschistes muscorum (5/2 333), Echium vulgare (5/1 3), Epipactis atrorubens 9/V 629), Equisetum arvense (1/I 1; 2// 1), E. hyemale (5/1 3), Euphrasia stricta $(4 / 13 ; 7 / I 1)$, Fallopia convolvulus (1/I 1;3/I 2), F. polesica (9/I 1), F. tenuifolia (9/II 64), Frangula alnus (9/I 1), Galium boreale (7// 1), G. mollugo (9/II 4), Geranium sanguineum (1/I 1; 8/I 1), Gypsophila fastigiata (9/II 1), Hieracium echioides (9// 1), H. Iaevigatum (8/I 1), Hypochoeris radicata (8/I 1), Hypogymnia physodes (8/I 2; 9/I 1), Juniperis communis b (8/I 1), Klebsormidium crenulatum (2/I 2; 6/I 1), Koeleria macrantha (7/I 1; 9/III 5), Lecanora conizaeoides (8/II 4), Medicago lupulina (5/1 3), Melampyrum pratense (8/I 138), Mnium rugicum (8/I 1), Trapeliopsis flexuosa (2/I 1), Oenothera acutifolia (4/1 3), O. pycnocarpa (1/I 1; 1/I 2; 4/1 3), O. royfraseri (1// 1), Padus virginiana (9// 1), Peltigera canina (7// 1), Pimpinella saxifraga (7/I 1), Poa trivialis (4/1 3), Pohlia nutans (1/I 1; 8/II 2), Polytrichum commune (1/I 1), P. juniperinum (3/I 2; 8/I 113), Populus x canescens (9/I 1), Prunus spinosa b/c (1// 1; 7/I 1), Pyrus pyraster (9/I 1), Quercus robur b/c (8/I 1; 9/II 1), Rosa canina (4/1 3), R. sherardii (1/I 1), Rubus saxatilis (1/I 1), Rumex acetosa (1/I 1), Salix acutifolia (9/V 3190), Senecio jacobaea (9/I 1), S. viscosus (3/I 2), Silene latifolia (1/I 1; 7/I 1), S. vulgaris (5/1 3), Solidago gigantea (1/I 1; 8/V 34), Taraxacum officinale (9/II 65), Tortula ruralis (3/I 2; 9/II 1), Trapeliopsis granulosa (8/I 1), Trifolium repens (9/I 1), Vaccinium vitis-idaea (8/I 1), Verbascum phlomoides (4/II 3), Vicia hirsuta (4/II 3), Viola arvensis (3/I 1) 


\section{References:}

Abromeit J., Jentzsch A. \& Vogel G., 1898, Flora von Ostund Westpreussen, 1 Hälfte, I-III Teil, In Kommission bei R. Friedländer und Sohn, Berlin.

Andrzejewski L., 2001, Ukształtowanie powierzchni terenu oraz budowa geologiczna. [Relief of the terrain and geological structure], [in:] A. Przystalski (ed.) Przyroda województwa kujawsko-pomorskiego Kujawsko-Pomorski Urząd Wojewódzki, Wojewódzki Konserwator Przyrody [Nature of the Kujawy-Pomerania Province, The Provincial Office of Kujawy and Pomerania, the Provincial Nature Conservation Officer], Bydgoszcz: 9-14.

Anikiejówna C. \& Gorska J., 1949, Stosunki florystyczne i fitosocjologiczne wydmy Zadroże [Floristic and phytosociological relations of the Zadroże Dune], Stud. Soc. Sc., Suppl. I, Toruń.

Boinski M., Cyzman W. \& Załuski T., 2001, Szata roślinna [Vegetation cover], [in:] A. Przystalski (ed.), Przyroda województwa kujawsko-pomorskiego. Kujawsko-Pomorski Urząd Wojewódzki, Wojewódzki Konserwator Przyrody [Nature of the Kujawy-Pomerania Province, The Provincial Office of Kujawy and Pomerania, the Provincial Nature Conservation Officer], Bydgoszcz: 54-77.

Brzeg A. \& Wojterska M., 2001, Zespoły roślinne Wielkopolski, ich stan poznania i zagrożenie [Plant communities of the Wielkopolska Region, the state of knowledge and the threats], [in:] M. Wojterska (ed.), Szata roślinna Wielkopolski i Pojezierza Południowopomorskiego, Przewodnik sesji terenowych 52 Zjazdu Polskiego Towarzystwa Botanicznego, 24-28 września 2001 [Vegetation cover of the Wielkopolska Region and the South Pomeranian Lake District, A guidebook to field sessions of the 52nd Convention of the Polish Botanical Society, September 24-28th, 2001], Bogucki Wyd. Nauk., Poznań: 39-110.

Burak S., 2001, Ochrona przyrody [Nature conservation], [in:] A. Przystalski (ed.), Przyroda województwa kujawsko-pomorskiego, Kujawsko-Pomorski Urząd Wojewódzki, Wojewódzki Konserwator Przyrody [Nature of the Kujawy-Pomerania Province, The Provincial Office of Kujawy and Pomerania, the Provincial Nature Conservation Officer], Bydgoszcz: 115-132.

Ceynowa-Giełdon M., 1984, Roślinność [Vegetation], [in:] R. Galon (ed.), Województwo toruńskie, Przyroda, ludność, osadnictwo i gospodarka [The Province of Torun, Nature, population, colonization and economy], PWN, Warszawa.

Ceynowa-Giełdon M. \& Nienartowicz A., 1994, Roślinność fortyfikacji dawnej twierdzy Toruń, Przewodnik. [Vegetation of fortifications of the former stronghold of Toruń, Guidebook], Toruńskie Tow. Nauk., Toruń.
Cieśliński S., Czyżewska K. \& Fabiszewski J., 2006, Red list of the lichens in Poland, [in:] Z. Mirek, K. Zarzycki, W. Wojewoda, Z. Szeląg (eds.) Red list of plants and fungi in Poland, W. Szafer Institute of Botany, Polish Academy of Sciences, Kraków: 71-89.

Diederich P., Ertz D., Stapper N., Sérusiaux E. \& Ries C., 2009, The lichens and lichenicolous fungi of Belgium, Luxembourg and northern France, URL, http://www. lichenology.info

Dorożyński R., 2001, mscr., Ogólna charakterystyka fizycznogeograficzna obszaru badań - Nadleśnictwo Gniewkowo [General physical and geographical description of the study area - the Forest Division of Gniewkowo], RDLP, Toruń.

Filinger D., 1992, Stanowisko kruszczyka rdzawoczerwonego Epipactis atropurpurea na nadmorskiej wydmie szarej [The location of dark-red helleborine Epipactis atropurpurea on a coastal grey dune],Chrońmy Przyr. Ojcz. 48(6): 74-76.

Hindák F., 1996, Klúč na určovanie nerozkonárených vláknitých zelenych rias (Ulotrichineae, Ulotrichales, Chlorophyceae), Bull. Slov. Bot. Spol. pri SAV, suppl. 1, Slovenska bot. spol. pri SAV, Bratislava.

Kaźmierczakowa R. \& Zarzycki K. (eds), 2001, Polska czerwona księga roślin. Paprotniki i rośliny kwiatowe [The Polish red data book of plants. Pteridophytes and flowering plants], Inst. Botaniki im. W. Szafera PAN, Instytut Ochrony Przyrody [W. Szafer Institute of Botany, Polish Academy of Sciences, Institute of Nature Conservation], Kraków.

Kępczyński K. \& Rutkowski L., 1988, Wybrane zbiorowiska psammofilnych turzyc w dolinie Wisły na odcinku Ciechocinek-Sztum [Selected communities of psammophilous sedges in the Vistula River valley along the section Ciechocinek-Sztum], Acta Univ. Nicolai. Copern. 63, Biologia 29: 6-15.

Klama H., 1996, Wątrobowce Beskidu Żywiecko-Orawskiego (Karpaty Zachodnie) [Liverworts of Beskid Żywiecko-Orawski (the Western Carpathians)], Monogr. Bot. 79: 1-144.

Klimaszewski M., 1978, Geomorfologia [Geomorphology], PWN, Warszawa.

Kondracki J., 2000, Geografia regionalna Polski [Regional geography of Poland], Wyd. Nauk. PWN, Warszawa.

Matuszkiewicz W., 2002, Przewodnik do oznaczania zbiorowisk roślinnych Polski [A guide for identification of plant communities in Poland], Vademecum geobotanicum, Wyd. Nauk. PWN, Warszawa.

Mirek Z., Piękoś-Mirkowa H., Zając A. \& Zając M., 2002, Flowering plants and pteridophytes of Poland. A checklist, Krytyczna lista roślin naczyniowych Polski [Critical list of vascular plants of Poland], Biodiversity of Poland, vol. 1., W. Szafer Inst. of Botany, Polish Acad. of Sciences, Kraków. 
Mrózek W., 1958, Wydmy Kotliny Toruńsko-Bydgoskiej [Dunes of the Torun-Bydgoszcz Valley], PWN, Warszawa.

Nowak J. \& Tobolewski Z., 1975, Porosty polskie [Polish lichens], PWN, Warszawa.

Ochyra R., Żarnowiec J. \& Bednarek-Ochyra H., 2003, Census catalogue of Polish Moses, Biodiversity of Poland, vol. 3, W. Szafer Inst. of Botany, Polish Acad. of Sciences, Kraków.

Orange A., James P. W. \& White F. J., 2001, Microchemical methods for the identification of lichens, British Lichen Society.

Pawłowski B., 1977, Skład i budowa zbiorowisk roślinnych oraz metody ich badania [The composition and structure of plant communities, as well as methods of their studies], [in:] W. Szafer, K. Zarzycki (eds), Szata roślinna Polski, t. 1 [The vegetation cover of Poland Vol. 1], PWN, Warszawa.

Preuss H., 1912, Die pontischen Pflanzenbestände im Weichselgebiet, [in:] H. Conwentz (ed.) Beiträge zur Naturdenkmalpflege 2, 4, Berlin: 350-540.

Purvis O. W., Coppins B. J., Hawksworth D. L., James P. W. \& Moore, D. M., 1992, The lichen flora of Great Britain and Ireland, Natural History Museum \& British Lichen Society, London.

Rejment-Grochowska J., 1971, Wątrobowce - Hepaticae [Liverworts], PWN, Kraków.

Rutkowski L., 1997, Rośliny naczyniowe - Tracheophyta [Vascular plants - Tracheophyta], [in:] L. Rutkowski (ed.), Czerwona lista roślin i zwierząt ginących i zagrożonych w regionie kujawsko-pomorskim [The red list of plants and animals at the risk of extinction and endangered ones in the Kujawy-Pomerania region], Acta Univ. Nicolai Copern., Biologia 53, suplement: 5-20.

Rutkowski L., 2004, Klucz do oznaczania roślin naczyniowych Polski niżowej [Identification key to vascular plants of lowland Poland], Wyd. Nauk. PWN, Warszawa.

Rutkowski L., 2005, Czerwona lista roślin naczyniowych zagrożonych w regionie kujawsko-pomorskim [The red list of endangered vascular plants in the Kujawy-Pomerania region], manuscript.

Santesson R., Moberg R., Nordin A., Tönsberg T. \& Vitikainen O., 2004, Lichen-forming and lichenicolous fungi of Fennoscandia, Museum of Evolution, Uppsala University, Uppsala.

Scholz J. B., 1896, Vegetationsverhältnisse des preussichen Weichselgeländes, Kommissions-Verlag von E. Lambeck, Thorn.

Symonides E., 1972, mscr., Spergula vernalis - ekologia i zmienność morfologiczna na różnych siedliskach wydmowych Kotliny Toruńskiej [Spergula vernalis - ecology and morphological variability on different dune habitats in the Torun Valley], Praca doktorska [Doctoral Thesis], NCU, Toruń.

Szafran B., 1957, 1961, Mchy t. 1, 2 [Mosses, Vol. 1, 2], PWN, Warszawa.

Szweykowski J., 2006, An annotated checklist of Polish liverworts and hornworts, Biodiversity of Poland, vol. 4., W. Szafer Inst. of Botany, Polish Acad. of Sciences, Kraków.

Walas J., 1969, Szata roślinna Kotliny Toruńskiej [Vegetation cover of the Torun Valley], Zesz. Nauk. UMK, Nauki Mat.-Przyr., Geografia 19(6): 161-186.

Wasilewski S., 2003, Zarys historii toruńskiego poligonu artyleryjskiego, Centrum Szkolenia Artylerii i Uzbrojenia im. Gen. J. Bema [An outline history of the artillery range in the city of Torun, General J. Bem Artillery and Armaments Training Centre], Toruń.

Wilkoń-Michalska J., 1971, Szata roślinna Kujaw, Przewodnik florystyczny [Vegetation cover of the Kujawy region, Floristic guidebook], Toruńskie Tow. Naukowe, Toruń.

Wojterski T., 1957, Zielonym szlakiem polskiego wybrzeża [Along the green route of the Polish coast], Wyd. Nasza Księgarnia, Warszawa.

Wojterski T. \& Bednorz J., 1982, Pobrzeże Słowińskie i Kaszubskie [Słowińskie and Kashubian Coast], Wyd. of General Knowledge, Warszawa. 